

\title{
Fine root growth and soil nutrient dynamics during shifting cultivation in tropical semi-evergreen forests of northeast India
}

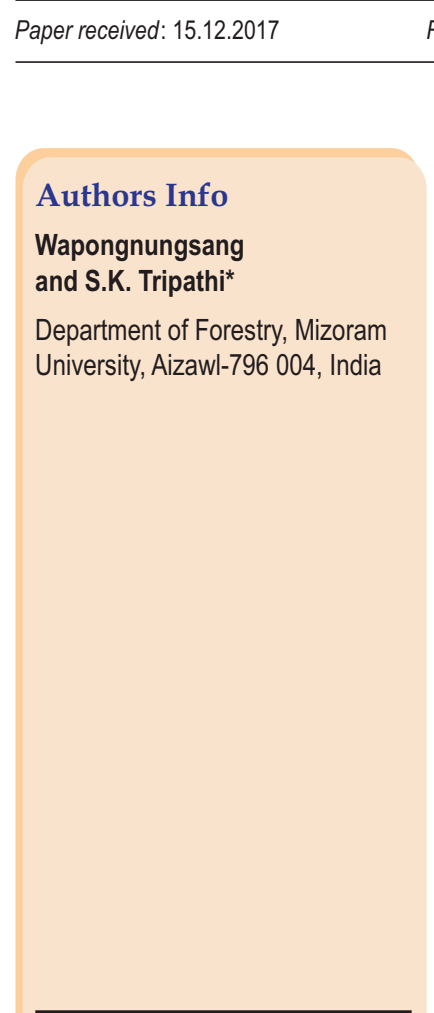

*Corresponding Author Email : sk_tripathi@rediffmail.com

\section{Edited by \\ Dr. Lungmuana Singson}

Reviewed by

Professor Ali Omer Uler Dr. Pedro Manuel Villa
Revised received: 06.05.2018

Re-revised received: 23.06 .2018

Accepted: 11.07 .2018

Abstract

Aim : The present study aimed to understand the periodical changes in fine root biomass, production, turnover and carbon and nitrogen return in forest fallows following shifting agriculture in Mizoram, Northeast India.

Methodology : Root biomass was determined using sequential coring method in different fallow lands (FL$3, \mathrm{FL}-5$ and FL-10) following shifting agriculture. Annual fine root production was calculated as the sum of differences between annual maximum and minimum root biomass of different diameter classes. Concentrations of carbon and nitrogen in soil and roots were determined using $\mathrm{CHN}$ auto-analyzer, and their accumulations and returns were computed as the product of mass and element concentrations.

Results : Total root biomass was maximum $\left(561 \mathrm{~g} \mathrm{~m}^{-2}\right)$ at FL-10, which decreased to $141 \mathrm{~g} \mathrm{~m}^{-2}$ at FL-3 with greater accumulation of fine roots in upper soil layer $(0-10 \mathrm{~cm})$ and coarse roots in lower depths. Root biomass was maximum (1499 $\mathrm{g} \mathrm{m}^{-2}$ ) at the time of slashing which decreased to about one fourth just after burning. The amount of organic matter, carbon and nitrogen return to soil through fine root death was significantly regulated by soil moisture, microbial biomass carbon and total nitrogen in differentfallowlands.

Interpretation : Addition of organic matter, carbon and nitrogen to soil through death and decomposition of fine roots is an important mechanism responsible for sustaining soil fertility and

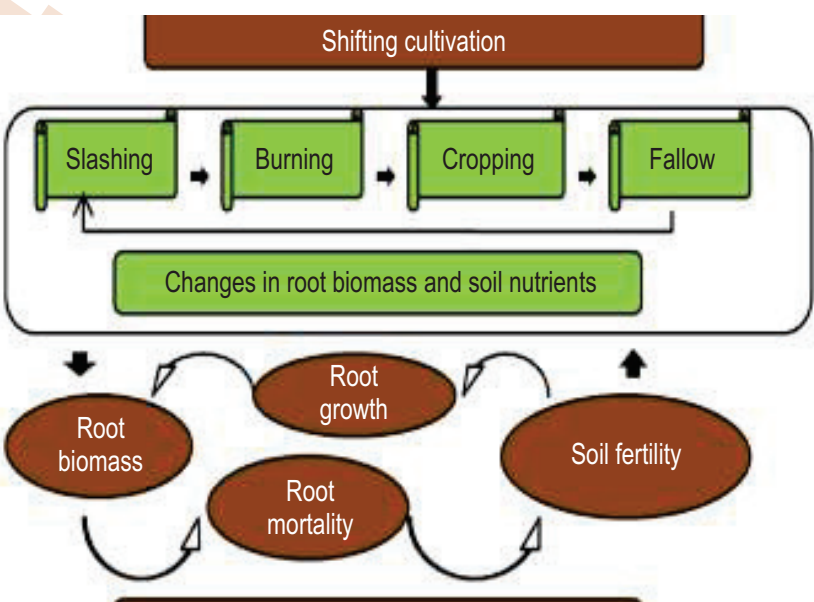

Significance of roots in soil fertility crop productivity in different fallow lands. The output of the study has implications for the management of fallow lands following shifting cultivation and modeling global cycles of carbon and nitrogen.

Key words: Fallow lands, Fine root biomass, Fine root turnover, Shifting cultivation, Subtropical semievergreen forest

How to cite: Wapongnungsang and S.K. Tripathi: Fine root growth and soil nutrient dynamics during shifting cultivation in tropical semi-evergreen forests of northeast India. J. Environ. Biol., 40, 45-52 (2019). 


\section{Introduction}

Shifting cultivation is one of the oldest forms of agriculture (Yadav, 2013) practiced by ethnic tribal populations in moist tropical forests of the world (Aweto, 2013; Delang and Li, 2013). The practice still continues and sustain $~ 500$ million people worldwide on about $40 \%$ of agricultural lands in the tropics (ITTO, 2002). During this practice, piece of forest land is slashed and burned by the village community followed by cropping for one or two years, and abandoning the land for few years to restore soil fertility (Jakovac et al., 2015; Villa et al., 2018). This practice has led to transform large area of the moist tropical forest into different stages of secondary succession with increasing proportion of young fallows due to increased population densities (Grogan et al., 2012). Roots have been reported to significantly affect the functioning of forest and have been reported to increase during forest development up to 100 years following disturbances (Yuan and Chen, 2010). Roots are central components in competitive equilibrium between crops and spontaneous re-growth (de Kroon et al., 2012), and in carbon-dynamics (Pan et al., 2011). However, the knowledge about the fine root growth dynamics is scarce largely due to methodological problems associated with the quantification of roots.

Frequent slash and burn of aboveground vegetation and shortening fallow-periods can favor plant survival-strategies in terms of maintenance of significant and well protected underground carbohydrate and nutrient reserves (Clarke et al., 2013). This may lead to increased belowground biomass, particularly fine roots in relation to aboveground biomass (Devagiri et al., 2013). Fine roots may contribute more carbon than aboveground parts to soil organic matter accumulation due to their higher inputs and faster decay rates (Bharbhuiya et al., 2012; Finer et al., 2011). Available research on fine roots in slash and burn fallows and disturbed tropical forest up to $1 \mathrm{~m}$ depth have shown shallow distribution of fine roots with majority concentrated in upper $10 \mathrm{~cm}$ (Jaoa et al., 2015).

Tropical secondary forests usually have rapid rates of aboveground production, especially during the initial stages of succession, but belowground gains represent the compartment with largest potential for continuous carbon accumulation (Klotzbücher et al., 2011). Fine roots contribute significantly to the biogeochemical cycling in forest ecosystems (Kardol and Wardle, 2010) because of their high growth and turnover rates. Several environmental factors affect fine root production and distribution such as climate seasonality, soil nutrients, soil temperature and moisture (Fukuzawa et al., 2010). Floristic composition has also been reported as important source of variation for fine-root production in forest successional stages (Singh et al., 2015).

Mizoram, a Northeast Indian state, is a hilly region supporting livelihood of different tribal populations through shifting agriculture which has been practiced for generations (Grogan et al., 2012). Soil erosion is a common phenomenon causing land degradation and deterioration of water quality in the region because of inappropriate land use and poor management systems which cause huge loss of fertile soil $\left(\sim 60 \mathrm{t} \mathrm{ha}^{-1}\right)$ every year through erosion (Tripathi et al., 2017). The objective of this study was to estimate periodical changes in fine root biomass, production, organic matter and nutrient turnover and soil nutrient dynamics in three fallow lands, following shifting agriculture in Northeast India. Further, soil water and nutrient were correlated with fine root biomass data to understand the role of various soil characteristics on fine biomass dynamics and carbon and nitrogen added in different fallow lands in Northeast India.

\section{Materials and Methods}

Study area : Mizoram is located in the northeastern part of India and covers an area of $21,081 \mathrm{~km}^{2}$. Mizoram is mainly mountainous with precipitous slopes forming deep gorges culminating into several streams and rivers. On the whole, Mizoram has a pleasant climate with temperature ranging between $20^{\circ} \mathrm{C}$ to $30^{\circ} \mathrm{C}$ during summer and from $11^{\circ} \mathrm{C}$ to $21^{\circ} \mathrm{C}$ during winter.

Shifting cultivation is a primitive form of agriculture commonly occurring in the moist tropical hilly regions of the world. In this practice of cultivation, farmers slash a piece of forest land, wait it to dry and burn the biomass in situ followed by cropping for few years depending on the soil fertility and abandon the land for 10-30 years to restore soil fertility through natural regeneration. During this period farmers move to other forested area for cultivation. This practice of cultivation is being followed in Northeast India for centuries. Earlier, the system was working well because of the long fallows of about $\sim 20$ years, however, during the course of time the fallow length has considerably decreased due to increase in population pressure that has decreased soil fertility and crop productivity, and posed a serious concern for food security for the local population. Thus, there is a need to understand the ecological principle underlying the shifting cultivation to sustain soil fertility and crop productivity in the region. The experiment was carried out in three different shifting cultivation sites (FL-3, FL-5 and FL-10) with 3, 5 and 10 year old fallow at Muallungthu Village of Aizawl District, Mizoram, Northeast India. Total annual rainfall during the study period (2013-14) ranged from $2300-2800 \mathrm{~mm}$. Soil moisture content (0$10 \mathrm{~cm}$ depth) at the study sites ranged from $16-18 \%$ in summer; $36-45 \%$ in rainy and $26-34 \%$ in winter, respectively.

Fine root biomass and production estimation : Root biomass was collected five times (i.e., at the time of slashing of forest vegetation, just after burning of biomass, at the time of seed sowing, at the time of crop maturity and at the time of crop harvest) a year (January-October 2013) from three secondary successional fallow stands. Five soil monoliths were collected at random locations from each stand and separated vertically into three depths $(0-10,10-20$ and $20-30 \mathrm{~cm})$. The samples were soaked in water and washed over sieve system to take out the root materials. The roots were divided into three different diameter classes: $\leq 0.5 \mathrm{~mm}, 0.5-2 \mathrm{~mm}, 2-5 \mathrm{~mm}$; oven dried at $80^{\circ} \mathrm{C}$ and weighed. Annual fine root production was calculated assuming a single annual pulse of fine root production 
and computed net production as the sum of differences between annual maximum and minimum root standing biomass of different diameter classes (Tripathi et al., 1999). Accumulations and inputs of carbon and nitrogen from roots to soil profiles were the product of root biomass and production data with their respective carbon and nitrogen concentrations. Turnover of root biomass was calculated as the ratio of annual net production to annual mean biomass. Similarly, turnover of carbon or nitrogen was calculated as annual input divided by annual mean accumulation of carbon or nitrogen in the soil profile.

Soil and root sampling and analysis : Soil samples (100-150 g) were collected from the upper (0-10 cm depth) soil surface from 12 random locations and composited as 4 replicated samples for each site. The composited soil samples were transported to the laboratory. Soil $\mathrm{pH}$ was measured in a soil-water suspension $\left(1: 2.5 \mathrm{w} / \mathrm{v}_{2} \mathrm{O}\right)$ using a digital $\mathrm{pH}$ meter. Gravimetric soil moisture was determined following the method of Anderson and Ingram (1993). Total soil carbon and Total soil nitrogen were determined by a Heraeus CHN-O-S Rapid Auto-analyzer using sulphanilamide $\left(\mathrm{C}_{6} \mathrm{H}_{8} \mathrm{~N}_{2} \mathrm{O}_{2} \mathrm{~S}\right)$ as a standard. Bicarbonate available phosphorus was estimated by ammonium molybdo-blue color method. Ammonium nitrogen $\left(\mathrm{NH}_{4}-\mathrm{N}\right)$ in soil was estimated by Indophenol Blue colour method. Soil nitrate nitrogen $\left(\mathrm{NO}_{3}-\mathrm{N}\right)$ was estimated by the method of Jackson (1958). Bulk density $\left(\mathrm{g} \mathrm{cm}^{-3}\right)$ was measured using a metallic tube of known inner volume to determine the dry weight of a unit volume of soil. Microbial biomass carbon and microbial biomass nitrogen content of the soil was determined by chloroform fumigation and extraction method (Brookes and Joergensen, 2006). Carbon and nitrogen concentrations in different root samples were analysed using
Haraeus CHNAuto Analyzer.

Statistical analyses : Statistical analyses was performed by SPSS Ver. 16 software (USA) for analysis of variance (one-way ANOVA) followed by Tukey's Honest Significant (HSD) test at $p \leq$ 0.05 significant level. Stepwise multiple regressions was tried to test the combined effects of different abiotic variables on fine root biomass.

\section{Results and Discussion}

The soils of the study sites were sandy to sandy loam in texture and strongly acidic in nature (Table 1). Soil pH increased with fallow ages and after burning, it gradually decreased later. The significant increase $(p<0.01)$ in soil $\mathrm{pH}$ with increase in fallow length may be associated with addition of more alkaline cations from burning of greater plant biomass in FL-10 than FL-3 (Granged et al., 2011). Significant decrease in soil bulk density from FL-3 $\left(1.04 \mathrm{~g} \mathrm{~m}^{-3}\right)$ to FL-10 $\left(0.72 \mathrm{~g} \mathrm{~m}^{-3}\right)$ may be attributed to increased accumulation of soil organic matter with fallow length (Hashim et al., 2016; Sarkar et al., 2015). The effect of burning on soil total carbon was not significant. However, soil microbial biomass carbon and microbial biomass nitrogen significantly increased $(p<0.01)$ from FL-3 to FL-10. The amount of total nitrogen, available phosphorus, nitrate nitrogen and ammonium nitrogen enhanced significantly $(p<0.01)$ with fallow age that indicates the increased input of organic residues and nutrient substrate in longer fallow (Lungmuana et al., 2017; Hauchhum and Tripathi, 2017). After burning, soil parameters like total nitrogen, Nmineralization rate and microbial activity decreased as a result of modified soil biochemical environment due increased temperature

Table 1 : Physico-chemical characteristics of surface soil $(0-10 \mathrm{~cm})$ of fallow stands of three ages $(3,5$ and 10 years which are represented as FL3, FL-5 and FL-10) $n=4$

\begin{tabular}{|c|c|c|c|c|c|c|c|c|c|}
\hline Periods & Sites & $\mathrm{pH}$ & TOC (\%) & TN (\%) & $\begin{array}{l}P_{\text {avail }} \\
(m g ~ k g\end{array}$ & $\begin{array}{l}\mathrm{NO}_{3}-\mathrm{N} \\
\left(\mathrm{mg} \mathrm{kg}^{-1}\right)\end{array}$ & $\begin{array}{l}\mathrm{NH}_{4}-\mathrm{N} \\
\left(\mathrm{mg} \mathrm{kg}^{-1}\right)\end{array}$ & $\begin{array}{l}\text { MBC } \\
\left(\mu g^{-1}\right)\end{array}$ & $\begin{array}{l}\text { MBN } \\
\left(\mu g g^{-1}\right)\end{array}$ \\
\hline \multirow[t]{3}{*}{$\overline{T S F}$} & FL-3 & $4.07^{\mathrm{a}}$ & $1.88^{a}$ & $0.053^{\mathrm{a}}$ & $4.97^{\mathrm{a}}$ & $36.07^{\mathrm{a}}$ & $59.95^{a}$ & $352.8^{\mathrm{a}}$ & $9.20^{\mathrm{a}}$ \\
\hline & FL-5 & $4.31^{\mathrm{ab}}$ & $2.17^{\mathrm{ab}}$ & $0.064^{b}$ & $6.21^{b}$ & $40.29^{b}$ & $71.83^{b}$ & $378.7^{\mathrm{ab}}$ & $11.06^{\mathrm{ab}}$ \\
\hline & FL-10 & $4.56^{\mathrm{c}}$ & $3.05^{\mathrm{bb}}$ & $0.082^{c}$ & $7.85^{\circ}$ & $45.27^{\circ}$ & $83.45^{c}$ & $390.3^{b b}$ & $12.24^{b b}$ \\
\hline \multirow[t]{3}{*}{$J A B$} & FL-3 & $4.20^{\mathrm{a}}$ & $2.29^{\mathrm{a}}$ & $0.047^{\mathrm{a}}$ & $4.61^{\mathrm{a}}$ & $31.16^{\mathrm{a}}$ & $45.85^{\mathrm{a}}$ & $243.7^{\mathrm{a}}$ & $6.64^{\mathrm{a}}$ \\
\hline & FL-5 & $4.34^{\mathrm{ab}}$ & $2.54^{\mathrm{ab}}$ & $0.055^{b}$ & $5.80^{\mathrm{b}}$ & $33.86^{b}$ & $55.76^{b}$ & $255.6^{\mathrm{ab}}$ & $9.97^{\mathrm{ab}}$ \\
\hline & FL-10 & $4.60^{\circ}$ & $2.69^{b b}$ & $0.076^{c}$ & $7.48^{\circ}$ & $37.99^{\circ}$ & $67.26^{c}$ & $264.8^{\mathrm{bb}}$ & $10.00^{\mathrm{bb}}$ \\
\hline \multirow[t]{3}{*}{ TSS } & FL-3 & $4.24^{\mathrm{a}}$ & $2.30^{\mathrm{a}}$ & $0.051^{\mathrm{a}}$ & $4.79^{\mathrm{a}}$ & $32.28^{\mathrm{a}}$ & $48.82^{\mathrm{a}}$ & $242.5^{\mathrm{a}}$ & $8.06^{\mathrm{a}}$ \\
\hline & FL-5 & $4.41^{\mathrm{ab}}$ & $2.56^{\mathrm{ab}}$ & $0.057^{\mathrm{b}}$ & $5.98^{\mathrm{b}}$ & $34.83^{b}$ & $57.49^{b}$ & $258.1^{\mathrm{ab}}$ & $10.59^{\mathrm{ab}}$ \\
\hline & FL-10 & $4.62^{\circ}$ & $2.70^{\mathrm{bb}}$ & $0.078^{c}$ & $7.71^{\circ}$ & $40.37^{\circ}$ & $72.49^{c}$ & $268.5^{\mathrm{bb}}$ & $10.79^{\mathrm{bb}}$ \\
\hline \multirow[t]{3}{*}{ TCM } & FL-3 & $4.29^{\mathrm{a}}$ & $2.41^{\mathrm{a}}$ & $0.053^{\mathrm{a}}$ & $5.07^{\mathrm{a}}$ & $34.22^{\mathrm{a}}$ & $56.08^{\mathrm{a}}$ & $257.57^{\mathrm{a}}$ & $9.21^{\mathrm{a}}$ \\
\hline & FL-5 & $4.32^{\mathrm{ab}}$ & $2.63^{\mathrm{ab}}$ & $0.060^{b}$ & $6.34^{\mathrm{b}}$ & $35.45^{b}$ & $62.89^{b}$ & $268.0^{\mathrm{ab}}$ & $12.11^{\mathrm{ab}}$ \\
\hline & FL-10 & $4.61^{\mathrm{c}}$ & $2.76^{\mathrm{bb}}$ & $0.079^{\circ}$ & $7.99^{\circ}$ & $42.66^{c}$ & $71.84^{\circ}$ & $304.3^{\mathrm{bb}}$ & $11.81^{\mathrm{bb}}$ \\
\hline \multirow[t]{3}{*}{$\mathrm{TCH}$} & FL-3 & $4.30^{\mathrm{a}}$ & $2.36^{a}$ & $0.055^{\mathrm{a}}$ & $5.29^{\mathrm{a}}$ & $35.23^{\mathrm{a}}$ & $59.67^{a}$ & $286.1^{\mathrm{a}}$ & $9.96^{\mathrm{a}}$ \\
\hline & FL-5 & $4.49^{\mathrm{ab}}$ & $2.57^{\mathrm{ab}}$ & $0.062^{b}$ & $6.53^{\mathrm{b}}$ & $36.28^{b}$ & $64.76^{b}$ & $305.1^{\mathrm{ab}}$ & $13.15^{\mathrm{ab}}$ \\
\hline & FL-10 & $4.72^{c}$ & $2.67^{\mathrm{bb}}$ & $0.083^{\mathrm{c}}$ & $8.30^{\circ}$ & $42.46^{c}$ & $74.07^{\circ}$ & $321.7^{\mathrm{bb}}$ & $12.56^{\mathrm{bb}}$ \\
\hline
\end{tabular}

Different small letters indicate statistically significant differences between fallow sites, $p<0.01$ and 0.05 . TSF $=$ Time of slashing of forest vegetation, $\mathrm{JAB}=$ Just after burning of biomass, $\mathrm{TSS}=$ Time of sowing seeds, $\mathrm{TCM}=$ Time of crop maturity, $\mathrm{TCH}=$ Time of crop harvest 


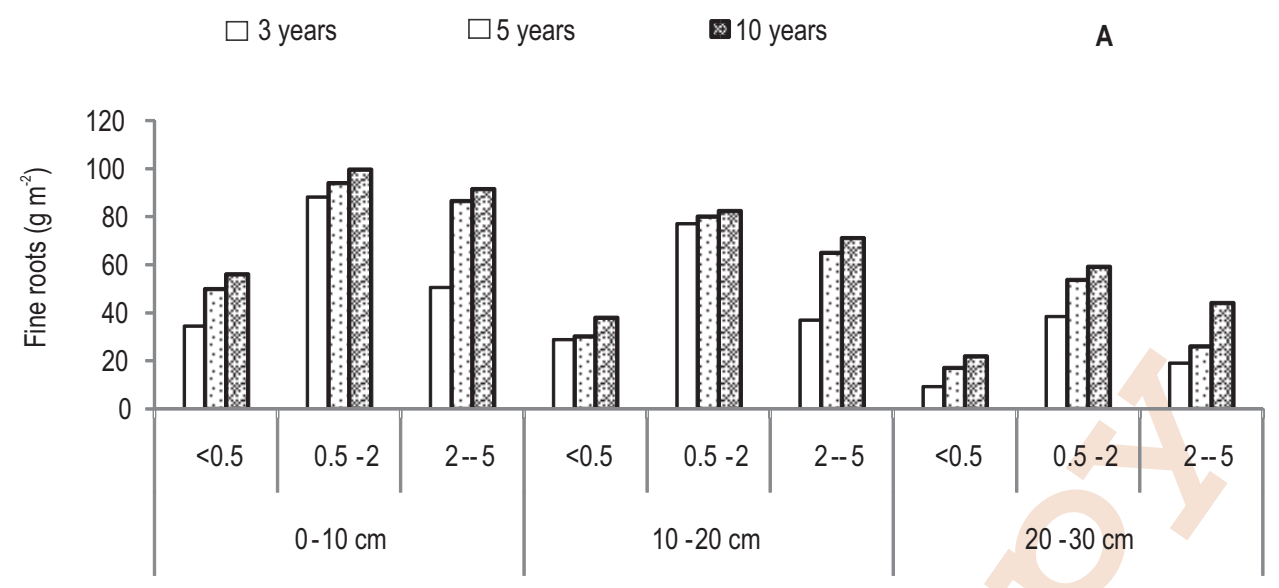

Soil depth and Root diameter wise
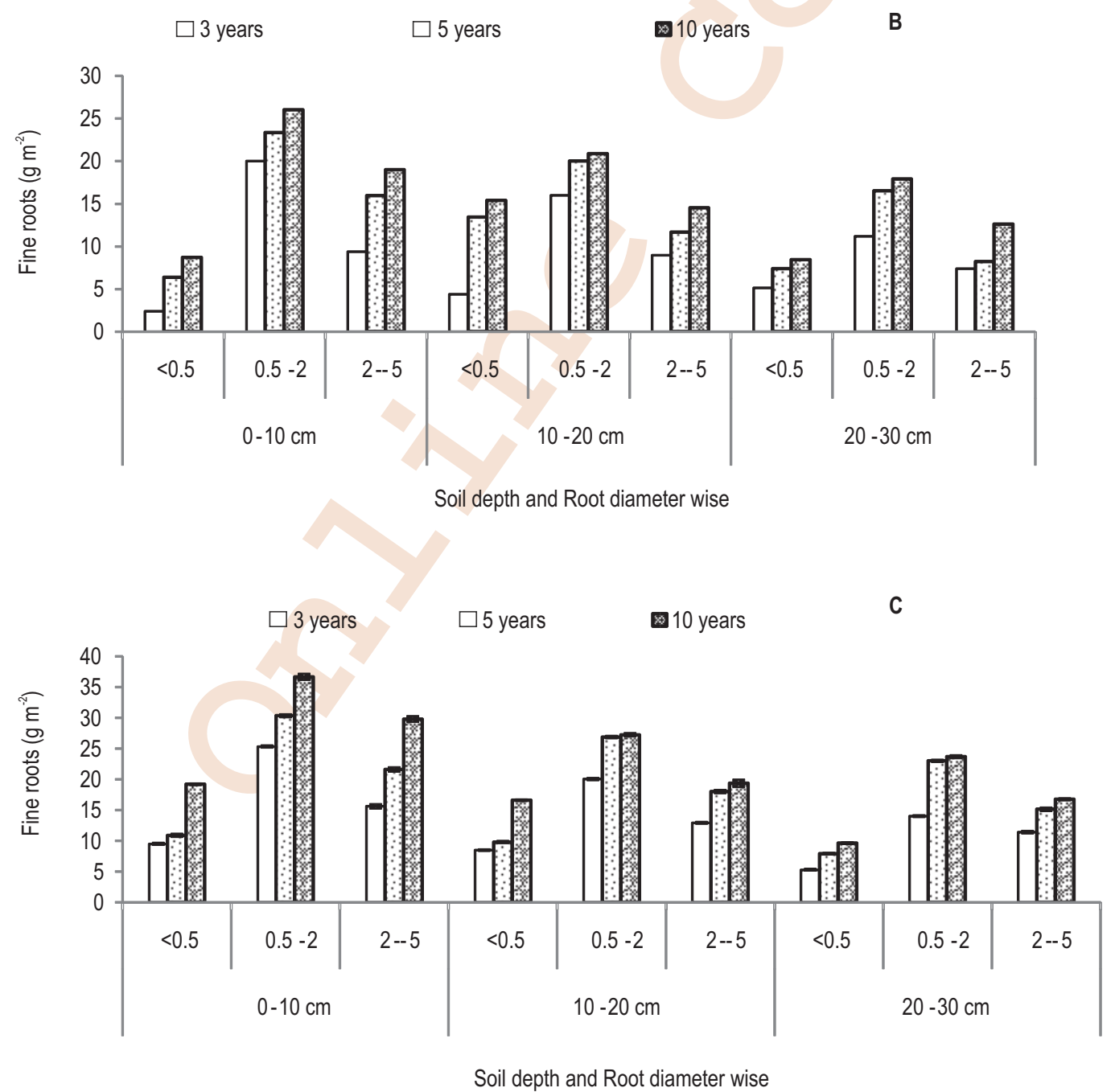

* Journal of Environmental Biology, January 2019 * 

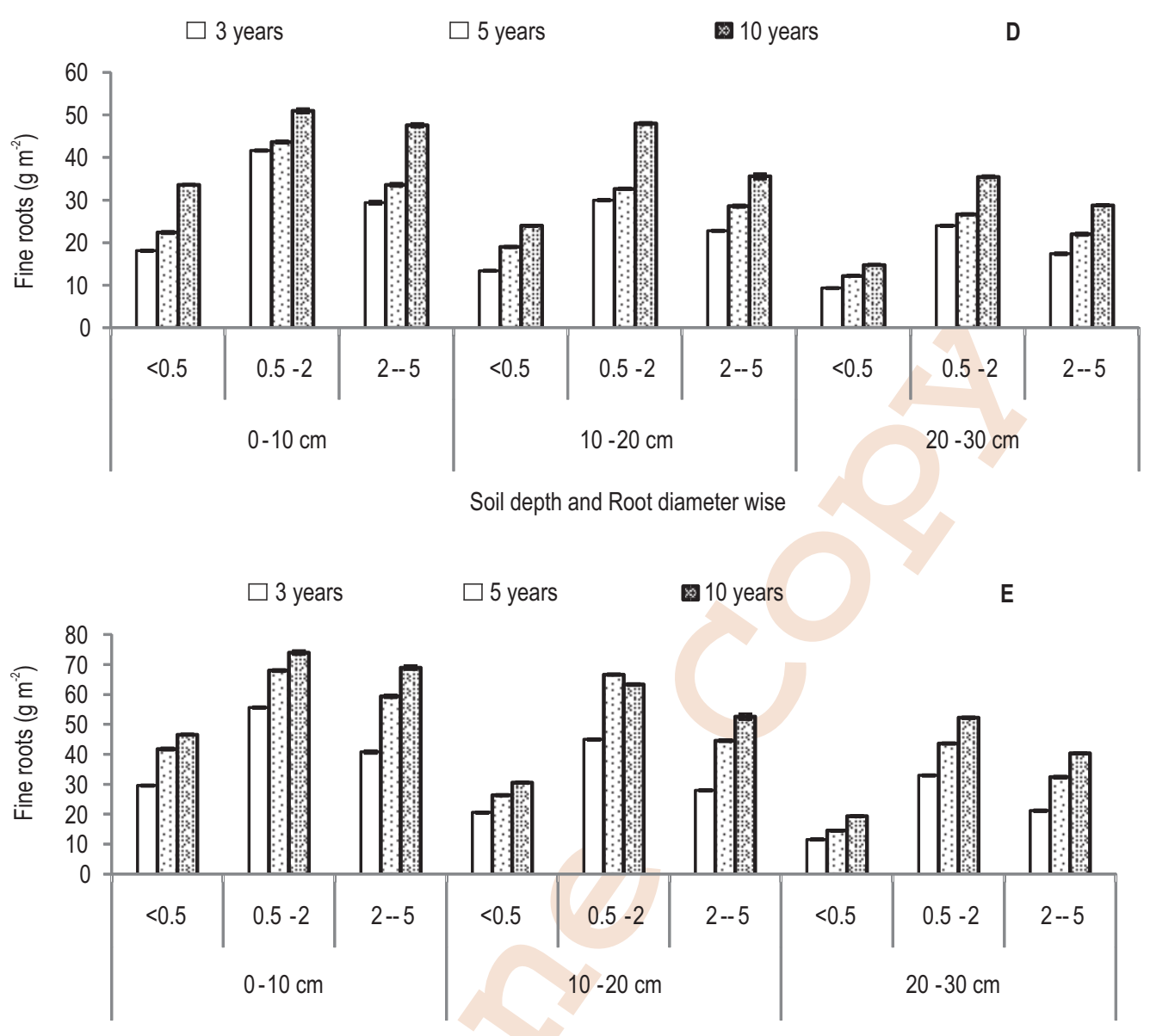

Soil depth and Root diameter wise

Fig. 1 : Depth wise seasonal variations in mean biomass of different diameter class root $\left(\mathrm{g} \mathrm{m}^{-2}\right)$ of three fallow stands. Seasonal biomass variations are represented by capital letters (A-E) which represent different stages of shifting cultivation, for example, (A) forest at the time of slashing, (B) just after burning of above ground biomass, $(C)$ at the time of seed sowing $(D)$ at the time of crop maturity and $(E)$ at the time of crop harvesting.

during burning (Lui et al., 2010), which gradually increased during the course of time.

Marked seasonal variations in root biomass were recorded in three fallow stands. For example, fine root biomass in the forest at the time of slashing was significantly $(p<0.05)$ different with that of fine root biomass post burning of aboveground biomass and at the time of seed sowing in three stands (FL-3, FL-5 and FL-10). Total root biomass was minimum post burning of aboveground biomass (e.g. 133, 149 and $175 \mathrm{~g} \mathrm{~m}^{-2}$, respectively, in FL-3, FL-5 and FL-10) and maximum at the time of slashing (e.g. 525, 577 and $671 \mathrm{~g} \mathrm{~m}^{-2}$, respectively, in FL-3, FL-5 and FL-10) (Fig.1). This could be due to rapid disappearance of root biomass, particularly at $0-10 \mathrm{~cm}$ soil depth post burning (Leppälammi-Kujansuu et al., 2014). Increased temperature due to burning may enhance root mortality and decomposition that may provide easily available soil nutrients to crop growth following burning. Among fallows, total root biomass showed significant $(p<0.05)$ increase from FL-3 $\left(277 \mathrm{~g} \mathrm{~m}^{-2}\right)$ to FL-10 $\left(396 \mathrm{~g} \mathrm{~m}^{-2}\right)$ (Fig. 1 ), which may be the result of decreased vegetation cover and soil fertility in younger fallow (Singh et al., 2015).

The present study showed that in all three fallows about $80 \%$ of roots were in the upper $10 \mathrm{~cm}$ soil depth and remaining in lower depths (Fig. 1). Therefore, it appears that the upper soil horizon permits a higher concentration of fine root tips which decreases towards lower soil layers as the soil nutrient content decreases. Nutrients that are released from the litter are not leached down the soil profile (Fukuzawa et al., 2007) but are transferred directly to the surface of the roots which are intermingled with the decaying matter. This may be one of the reasons for the greater fine root production in the top $10 \mathrm{~cm}$ of soil in this study. Significant spatio-temporal variations were recorded in the amount of total root biomass at different time points (e.g. in 


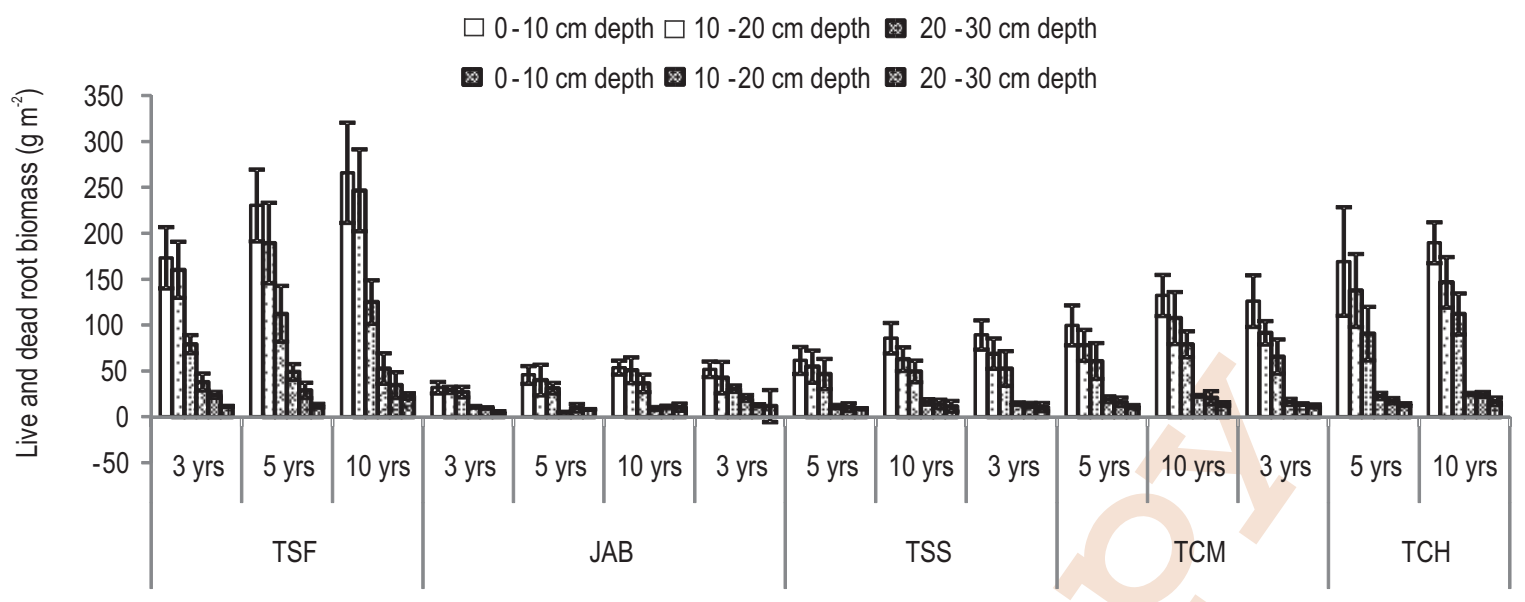

Fig. 2 : Live and dead root biomass in three Jhum fallow stands of various ages ( 3,5 and 10 years represented by FL-3, FL- 5 and FL-10) up to $30 \mathrm{~cm}$ soil depth. Different Jhum cycles are represented as: TSF- forest at the time of slashing, JAB-just after burning of aboveground biomass, TSS- at the time of seed sowing, TCM-at the time of crop maturity and TCH- at the time of crop harvesting. Vertical lines indicate standard error $\pm 1 S E, n=15$.

the forest at the time of slashing, at the time of seed sowing, at the time of crop maturity and at the time of crop harvest), except just after burning of aboveground biomass in three fallows $(F(4,20.7)$ $=73.2 ; p<0.001 ; R$ square $=0.914)$. Similarly, live fine root changed significantly $(p<0.01)$ during various cropping events, for example, $451-561 \mathrm{~g} \mathrm{~m}^{-2}$ at the time of slashing, 88-141 $\mathrm{g} \mathrm{m}^{-2}$ just after burning of aboveground biomass, $125-198 \mathrm{~g} \mathrm{~m}^{-2}$ at the time of seed sowing, $211-319 \mathrm{~g} \mathrm{~m}^{-2}$ at the time of crop maturity and 283-448 $\mathrm{g} \mathrm{m}^{-2}$ at the time of crop harvest in three fallows (Fig. 2).

Seasonal variations in dead root were less marked during various cropping events, but the marked variations were observed with different fallow. This could be due to conversion of total live roots into dead category after burning, followed by decomposition and death of new roots during cropping phase (Kitajima et al., 2010). Soil moisture was significantly $(p<0.01)$ and positively correlated with total root biomass in FL-3 $\left(R^{2}=0.22\right), F L-5\left(R^{2}=0.44\right)$ and $F L-10\left(R^{2}=0.31\right)$. Further, total nitrogen and microbial biomass carbon were also significantly and positively correlated with total root biomass in FL-3 $\left(R^{2}=0.22\right.$ and $\left.R^{2}=0.51\right), F L-5\left(R^{2}=0.24\right.$ and $\left.R^{2}=0.75\right)$ and 10 years $\left(R^{2}=0.21\right.$ and $\left.R^{2}=0.52\right)$. In this study, maximum root biomass at the time of crop maturity and minimum just after burning of biomass suggests positive correlations of root biomass with soil moisture, total nitrogen and microbial biomass carbon. These soil variables were found to play a significant role in determining the distribution of roots, particularly in the upper soil profile which contained greater mass of fine roots than other soil depths, thus, fine roots with higher nitrogen concentrations show significant correlations with soil nitrogen content (Du et al., 2013; Yuan and Chen, 2010).

While carbon concentration increased with root diameter, the concentration of nitrogen decreased significantly $(p<0.01)$. Gordon and Jackson (2000) found significant inverse relationship of root diameter with nitrogen concentrations. Comas and Eissenstat $(2009)$ found significant $(p<0.01)$ positive correlation with carbon content. The carbon: nitrogen ratio ranged from 14-16, $15-17$ and $16-18$, respectively, at $<0.5 \mathrm{~mm}, 0.5-2 \mathrm{~mm}$ and $2-5 \mathrm{~mm}$ diameter roots at all study sites (Table 2). Total accumulation of carbon and nitrogen by different root categories differed significantly $(p<0.5)$ in the soil profile to a depth of $30 \mathrm{~cm}$ in different fallow lands. The accumulation of carbon and nitrogen within soil profile generally followed the pattern similar to that of total organic

Table 2: Changes in carbon and nitrogen concentrations (\%) and carbon: nitrogen ratios of roots of different diameter classes in three fallow stands

\begin{tabular}{lllll}
\hline Fallow stands & Root categories & Carbon (\%) & Nitrogen (\%) & Carbon : Nitrogen ratio \\
\hline FL-3 & $<0.5 \mathrm{~mm}$ & 32.8 & 2.09 & 15.68 \\
& $0.5-2 \mathrm{~mm}$ & 33.6 & 1.98 & 16.98 \\
& $2-5 \mathrm{~mm}$ & 34.7 & 1.91 & 18.15 \\
FL-5 & $<0.5 \mathrm{~mm}$ & 34.2 & 2.24 & 15.25 \\
& $0.5-2 \mathrm{~mm}$ & 35.5 & 2.18 & 16.30 \\
FL-10 & $2-5 \mathrm{~mm}$ & 36.4 & 2.05 & 17.74 \\
& $<0.5 \mathrm{~mm}$ & 36.6 & 2.56 & 14.28 \\
& $0.5-2 \mathrm{~mm}$ & 37.8 & 2.48 & 15.25 \\
\hline
\end{tabular}

The values are mean of fifteen replicates \pm SE 
Table 3 : Accumulation, production and input of organic matter, carbon and nitrogen through roots categories in soil profile to a depth of $30 \mathrm{~cm}$ and turnover of organic matter in different fallows in Muallungthu village

\begin{tabular}{|c|c|c|c|c|c|c|c|c|c|c|}
\hline \multicolumn{2}{|c|}{ Fallow age/depth $(\mathrm{cm})$} & \multicolumn{2}{|c|}{ Accumulation (kg ha-1) } & \multicolumn{2}{|c|}{ Input (kg ha $\left.{ }^{-1}\right)$} & \multicolumn{3}{|c|}{ Annual production (kg ha-1) } & \multicolumn{2}{|c|}{ Turnover rate (year ${ }^{-1}$ ) } \\
\hline & $\mathrm{OM}^{*}$ & $C$ & $\mathrm{~N}$ & $\mathrm{OM}^{*}$ & $\mathrm{C}$ & $\mathrm{N}$ & $\mathrm{OM}^{*}$ & $\mathrm{C}$ & $\mathrm{N}$ & $\mathrm{OM}^{*}$ \\
\hline \multicolumn{11}{|c|}{3 years } \\
\hline $0-10$ & 1147 & 426 & 23 & 1709 & 635 & 34 & 1020 & 379 & 20 & 0.89 \\
\hline $10-20$ & 947 & 351 & 19 & 1483 & 550 & 30 & 640 & 238 & 13 & 0.68 \\
\hline $20-30$ & 695 & 258 & 14 & 922 & 342 & 18 & 462 & 171 & 9 & 0.66 \\
\hline Total & 2789 & 1036 & 56 & 4114 & 1528 & 82 & 2122 & 788 & 42 & \\
\hline \multicolumn{11}{|c|}{5 years } \\
\hline $0-10$ & 1427 & 571 & 333 & 2284 & 913 & 52 & 1411 & 564 & 32 & 0.99 \\
\hline $10-20$ & 1153 & 461 & 226 & 1510 & 6034 & 35 & 1002 & 401 & 23 & 0.87 \\
\hline $20-30$ & 733 & 293 & 17 & 480 & 192 & 11 & 606 & 242 & 14 & 0.83 \\
\hline Total & 3313 & 1325 & 76 & 4274 & 1709 & 98 & 3020 & 1208 & 69 & \\
\hline \multicolumn{11}{|c|}{10 years } \\
\hline $0-10$ & 1668 & 667 & 40.0 & 2368 & 947 & 57 & 1518 & 607 & 36 & 0.91 \\
\hline $10-20$ & 1325 & 530 & 332 & 1618 & 647. & 39 & 1090 & 436 & 26 & 0.82 \\
\hline $20-30$ & 962 & 385 & 23 & 977 & 3901 & 23 & 790 & 316 & 19 & 0.82 \\
\hline Total & 3955 & 1582 & 95 & 4963 & 1985 & 119 & 3398 & 1359 & 82 & \\
\hline
\end{tabular}

$\mathrm{OM}^{*}=$ organic matter. Turnover rates of $\mathrm{C}$ and $\mathrm{N}$ were almost similar to that of $\mathrm{OM}$

matter (root biomass). The maximum organic matter, carbon and nitrogen were accumulated in upper soil depth followed by lower depths $(0-10 \mathrm{~cm})$. Accumulation of carbon and nitrogen were greater at FL-10 compared to FL-3 and FL-5 (Table 3). Of the total carbon and nitrogen accumulated within 0-30 depth, maximum $(42-44 \%)$ occurred at 0-10 cm soil depth and minimum (22-25\%) at $20-30 \mathrm{~cm}$ in three fallow stands (Barbhuiya et al., 2012). The fine root turnover rates in the present study $\left(0.66-0.99 \mathrm{yr}^{-1}\right)$ were comparable to the range $\left(0.77-1.44 \mathrm{yr}^{-1}\right)$ reported for different forests like boreal, temperate and tropical forests across different locations. (Finer et al., 2011; Yuan and Chen, 2010). In the present study, root production increased with the age of fallow which indicates that the root growth is strongly affected by soil fertility of the site. Fine root production and turnover have also been reported to vary due to site quality and species composition in forest ecosystem (Fukuzawa et al., 2013; ; Singh et al., 2015).

Fine roots have been widely reported to play an important role in the functioning of variety of natural forests and modified ecosystems by adding about $40-50 \%$ organic matter, carbon and nutrients. In the present study, of the total accumulation ( $\left.\mathrm{kg} \mathrm{ha}^{-1}\right)$ of 2789-3955 organic matter, 1036-1582 carbon and 56-95 nitrogen in roots to 30 depth, roots returned 4114-4963 organic matter, 1528-1985 carbon and 82-119 nitrogen (Table 3) in different fallow lands following burning due to root death. The addition of nutrients from dead roots may be an important mechanism that may sustain soil fertility and crop productivity in shifting agriculture. In conclusion, shorter Jhum fallow with reduced soil fertility produces proportionately greater amount of fine roots $(<0.5 \mathrm{~mm}$ ) compared to older jhum fallow to exploit more soil nutrients from greater soil volume. Additionally, these roots add substantial amount of organic matter and nutrients to the soil through their rapid turnover rates $(<1$ year) that accelerate the process of recovery at these sites. It is suggested that varying quantity and quality of different categories of fine roots with different turnover rates play a significant role in secondary succession in semi-evergreen subtropical forests of Mizoram. This study may be useful for the management of Jhum fallow lands in Mizoram.

\section{Acknowledgments}

We thank Department of Biotechnology, Government of India for financial support in the form of a research project. Department of Forestry, Mizoram University is thankfully acknowledged for providing laboratory facilities. We are thankful to Dr. C. Lalnunzira for his assistance in the field work. We also thank farmers for their open-hearted co-operation for sharing experience and access to fields.

\section{References}

Aweto, A.O.: Shifting Cultivation and Secondary Succession in the Tropics. CABI, Wallingford, UK (2013).

Anderson, J.M. and I.S.I. Ingram: Tropical Soil Biology and Fertility-A Handbook of Methods. $2^{\text {nd }}$ Edn. , CAB International, Wallingford, UK (1993).

Barbhuiya, A.R., A. Arunachalam, H.N. Pandey, M. L. Khan and K. Arunachalam: Fine root dynamics in undisturbed and disturbed stands of a tropical wet evergreen forest in northeast India. Tropical Ecology, 53, 69-79 (2012).

Brookes, P.C. and R.G. Joergensen: Microbial biomass measurements by fumigation extraction. In: Microbiological Methods for Assessing Soil Quality (Eds. : J. Bloom, D.N. Hopkins and A. Benedetti). CABI Publishing, Oxfordshire, UK, pp. 77-83 (2006). 
Clarke, P., M. Lawes, J. Midgley, B. Lamont, F. Ojeda, G. Burrows, N. Enright and K. Knox: Resprouting as a key functional trait: How buds, protection and resources drive persistence after fire. New Phytol., 197, 19-35 (2013).

Comas, L.H. and D.M. Eissenstat: Patterns in root trait variation among 25 co-existing North American forest species. New Phytol.,182, 919-928 (2009).

Delang, C.O., W.M. Li: Ecological succession on fallowed shifting cultivation fields: A review of the literature. Springer Dordrecht Heidelberg, New York (2013).

Devagiri, G.M., S. Money, S. Singh, V.K. Dadhawal, P. Patil, A.K. Khaple, A.S. Davakumar and S. Hubballi: Assessment of above ground biomass and carbon pool in different vegetation types of south western part of Karnataka, India using spectral modeling. Trop. Ecol., 54, 149-165(2013).

Du Z.Y., Q.H. Wang, S.J. Xing, F.C. Liu, B.Y. Ma, H.L. Ma and D.X. Liu: Fine root distribution, characteristics and rhizosphere soil properties in a mixed stand of Robinia pseudoacacia and Fraxinus velutina in a saline soil. Silva Fennica, 47, 970 (2013).

de Kroon, H., M. Hendriks, J. Van Ruijven, J. Revenek, F.M. Padela, E. Jongejans, E.J.W. Visser and L. Mommer: Root response to nutrient and soil biota: Drivers of species coexistence and ecosystem productivity. J. Ecol., 100, 6-15(2012).

Finer, L., M. Ohashi, K. Noguchi and Y. Hirano: Fine root production and turnover in forest ecosystems in relation to stand and environmental characteristics. For. Ecol. Manage., 262, 2008$2023(2011)$

Fukuzawa, K., H. Shibata, K. Takagi, F. Satoh, T. Koike and K. Sasa: Temporal variation in fine-root biomass, production and mortality in a cool temperate forest covered with dense understory vegetation in Northern Japan. For. Ecol. Manage., 310, 700-710 (2013).

Fukuzawa, K., M. Dannoura, S. Kanemitsu and Y. Kosugi: Seasonal patterns of root production of Japanese oak seedlings and dwarf bamboo grown in rhizoboxes. Plant Biosys., 144, 434-439 (2010).

Fukuzawa, K., H. Shibata, K. Takagi, F. Satoh, T. Koike and K. Sasa: Vertical distribution and seasonal pattern of fine-root dynamics in a cool-temperate forest in Northern Japan: Implication of the understory vegetation, Sasa dwarf bamboo. Ecol. Res., 22, 485495 (2007)

Gordon, W.S. and R.B. Jackson: Nutrient concentration in fine roots. Ecology, 81, 275-280 (2000).

Granged, A.J.P., L.M. Zavala, A. Jordan and G.B. Moreno: Post-fire evolution of soil properties and vegetation cover in a Mediterranean heath land after experimental burning: A three year study. Geoderma, 164, 85-94 (2011).

Grogan, P., F. Lalnunmawia and S.K. Tripathi: Shifting cultivation in steeply sloped regions: A review of management options and research priorities for Mizoram state, Northeast India. Agrofor. Syst., 84, 163-177 (2012).

Hashim, M., S. Dhar, A.K. Vyas and C.B Singh: Yield trends in changes in physical-chemical properties of soil in maize-wheat cropping system under integrated cropping management. J. Environ. Biol., 38, 727-734 (2016).

Hauchhum, R. and S.K. Tripathi: Rhizosphere effects of Malocanna baccifera on soil microbial properties under different fallow phases following shifting cultivation. Int. J. Plant Soil Sci., 17, 1-9 (2017).

ITTO: ITTO Guidelines for the Restoration, Management and Rehabilitation of Degraded and Secondary Tropical Forest. ITTO Policy Development Series No 13. International Tropical Timber Organization in collaboration with CIFOR, FAO, IUCN, WWF International (2002).

Jackson, M.L.: Soil Chemical Analysis. Prentice Hall, Englewood Cliffs, New Jersey (1958).

Jakovac, C.C., M. Peña-Claros, T.W. Kuyper, F. Bongers: Loss of secondary-forest resilience by land-use intensification in the
Amazon. J. Ecol., 103, 67-77 (2015)

Jaoa de, S.T.R., H.R.M. Flavio and C. Gehring: Root biomass in a shifting cultivation system in the eastern periphery of Amazonia and contribution of the babassu palm. Agrofor. Syst., 90, 351-360 (2015).

Kardol, P. and D.A. Wardle: How understanding aboveground-belowground linkages can assist restoration ecology. Trends Ecol. Evol., 25, 670679 (2010).

Kitajima, K., K.E. Anderson and M.F. Allen: Effect of soil temperature and soil water content on fine root turnover rate in a California mixed conifer ecosystem. J. Geophysic. Res. Biogeosci., 115, G04032 (2010).

Klotzbücher, T., K. Kaiser, G.D. Guggenberger, C. Gatzek and K. Kalbitz A new conceptual model for the fate of lignin in decomposing plant litter. Ecology, 92, 1052-1062 (2011).

Leppalammi-Kujansuu, J., M. Salemaa, D.B. Kleja, S. Linder and H.S. Helmisaari: Fine root turnover and litter production of Norway spruce in a long-term temperature and nutrient manipulation experiment. Plant Soil, 374, 73-88 (2014).

Leuschner, C., M. Wiens, M. Herteveld, D. Hertel and S. Tjitrosemito: Pattern of fine root biomass and distribution along a distribution gradient in a tropical montane forest Central Sulawesi (Indonesia). Plant Soil, 283, 163-174 (2006).

Liu, W., W. Xu, J. Hong and S. Wan: Interannual variability of soil microbial biomass and respiration in responses to topography, annual burning and $\mathrm{N}$ addition in a semi-arid temperate steppe. Geoderma, 158, 259-267 (2010).

Lungmuana, S.B. Singh, Vanthawmliana, S. Saha, S.K. Dutta, Rambuatsaiha, A.R. Singh and T. Boopathi: Impact of secondary forest fallow period on soil microbial biomass carbon and enzyme activity dynamics under shifting cultivation in North Eastern hill region, India. Catena, 156, 10-17 (2017).

Pan, Y., R.A. Birdsey, J. Fang, R. Houghton, P.E. Kauppi, W.A. Kurz, O.L. Phillips, A. Shvidenko, S.L. Lewis, J.G. P. Canadell, Ciais, R.B Jackson, S.W. Pacala, A.D. McGuire, S. Piao, A. Rautiainen, S. Sitch and D. Hayes: A large and persistent carbon sink in the world's forests. Science, 333, 988-993 (2011).

Sarkar, D., ChB. Meitei, L.K. Baishya, A. Das, S. Ghosh, K.L. Chongloi and D. J. Rajkhowa: Potential of fallow chronosequence in shifting cultivation to conserve soil organic carbon in Northeast India. Catena, 135, 321-327 (2015).

Schrestha, B.M. and H.Y.H. Chen: Effects of stand age, wildfire and clear cut harvesting on forest floor in boreal mix wood forests. Plant Soil, 336, 267-277 (2010).

Singh, Sh.B., B.P. Mishra and S.K. Tripathi: Recovery of plant diversity and soil nutrients during stand development in subtropical forests of Mizoram, Northeast India. Biodivesritas, 16, 205-212 (2015).

Tripathi, S.K., D.C. Vanlalfakawma and F. Lalnunmawia: Shifting cultivation on steep slopes of Mizoram, India: Impact of policy reforms, In: Shifting Cultivation Policies: Balancing Environmental and Social Sustainability (Ed.: M. Cairns). CABI, Wallingford, Oxfordshire, UK, pp. 395-413 (2017).

Tripathi, S.K., K.P. Singh and P.K. Singh: Temporal changes in spatial pattern of fine root biomass and nutrient concentrations in Indian Bamboo savanna. Appl. Vege. Sci., 2, 229 -238 (1999).

Yadav, P.K.: Slash and burn agriculture in North-East India. Expert Opin. Environ. Biol., 2, 1-4 (2013).

Yuan, Z.Y. and H.Y.H. Chen: Fine root biomass, production, turnover rates and nutrient contents in boreal forest ecosystem in relation to species, climate, fertility and stand age: Literature review and meta-analysis. Crit. Rev. Plant Sci., 29, 204-221 (2010).

Yuan, Z.Y. and H.Y.H. Chen: Fine root dynamics with stand development in the boreal forest. Functional Ecol., 26, 991-998 (2012).

Villa, P.M., S.V. Martins, S.N. Oliveira Neto, A.C. Rodrigues, L. Martorano, L. Delgado, N.M. Cancio, M. Gastauerg: Intensification of shifting cultivation reduces forest resilience in the northern Amazon For Ecol Manage. 430, 312-320 (2018). 